\title{
Non ST Elevation Myocardial Infarction after an Allergic Reaction: Type II Kounis Syndrome
}

\author{
Allerjik Reaksiyon Sonrası Gelişen ST Elevasyonu Olmayan Kalp Krizi: \\ Tip II Kounis Sendromu
}

\author{
Ahmet Oğuz Baktır', Bahadır Şarlı', Hayrettin Sağlam', Hüseyin Arınç¹, Mustafa Oğuz Cumaoğlu², Yasemin Doğan' \\ 'Department of Cardiology, Kayseri Education and Research Hospital, Kayseri, Turkey \\ 2Department of Emergency Medicine, Kayseri Education and Research Hospital, Kayseri, Turkey
}

\section{ABSTRACT}

Introduction: Myocardial infarction due to an allergic reaction is called the Kounis Syndrome. The present case is an example of Type II variant.

Case Report: The present case report represents a 70 year old female with the diagnosis of non ST elevation myocardial infarction (NSTEMI). NSTEMI occured after an allergic reaction due to metimazol sodium and aggravated by ampicilin/sulbactam. Kounis Syndrome includes three types of myocardial infarction. The present case is an example of Type II variant.

Conclusion: The patient was treated by stenting three stenoses on two coronary arteries and the final diagnosis was type II Kounis Syndrome.

Keywords: Kounis syndrome, type II kounis syndrome, myocardial infarction

Received: 04.01.2013 Accepted: 04.02.2013

\section{ÖZET}

Giriş: Allerjik reaksiyon sonrası oluşan kalp krizi Kounis sendromu olarak adlandırılır. Olgumuz tip 2 çeşitini içermektedir.

Olgu Sunumu: Olgu sunumumuzda ST yükselmesiz kalp krizi teşhisi konulan 70 yaşında bayan hastayı bildirmekteyiz. Metimazol sodyuma bağlı gelişen ve ampisilin/sulbactam ile alevlenen allerjik reaksiyon sonrasında ST yükselmesiz kalp krizi gelişmiştir. Kounis sendromunun üç tipi bulunmaktadır. Mevcut olgu Tip II'nin örneğidir.

Sonuç: Hastanın iki koroner arterinde oluşan üç darlık, stentleme yöntemi ile tedavi edilmiş ve sonuç olarak Tip II Kounis sendromu tanısı konulmuştur.

Anahtar Kelimeler: Kounis sendromu, tip II Kounis sendromu, kalp krizi

Geliş Tarihi: 04.01.2013 Kabul Tarihi: 04.02.2013

\section{Introduction}

The present case report represents a 70 year old female with the diagnosis of non ST elevation myocardial infarction (NSTEMI). NSTEMI occurred after an allergic reaction due to metimazol sodium and aggravated by ampicillin/sulbactam. This type of myocardial infarction is defined as the Kounis Syndrome which includes three types. Type I variant includes patients with normal coronary arteries. Type II variant includes patients with underlying atheromatous disease and type III, the most recently described type, includes stent thrombosis as a result of hypersensitivity to drug eluting stents. The patient was treated by stenting three stenoses on two coronary arteries and the final diagnosis was type II Kounis Syndrome.

\section{Case Report}

A seventy year old female patient was admitted to intensive care unit with symptoms of dyspnea and erythematous lesions on the gluteal area after an allergic reaction due to administration of metimazol sodium for headache. The patient was then referred to our hospital for further evaluation and monitorisation in the intensive care unit with the diagnosis of toxic epidermal necrosis. Lesions on the gluteal area had become necrotic over time. Treatment with ampicillin/sulbactam was initiated. After the first dosage of 
ampicillin/sulbactam, an anaphylactoid reaction leading to cardiopulmonary arrest was occurred. After successful cardiopulmonary resuscitation, the patient was immediately transferred to the coronary care unit with the diagnosis of non ST elevation myocardial infarction (NSTEMI). The troponin level was high and there were ischemic ST changes on electrocardiography (ECG) (Figure 1). The patient's past medical history revealed hypertension, smoking, allergic reactions and noncritical stenosis on previous coronary angiography. Physical examination after cardiopulmonary resuscitation was normal and blood pressure was 130/80 $\mathrm{mmHg}$ and pulse rate $80 / \mathrm{min}$. Medication including acetylsalicylic acid 300 mg/day, clopidogrel 75 mg/day, atorvastatin $40 \mathrm{mg} /$ day, perindopril $5 \mathrm{mg} /$ day, amlodipin $10 \mathrm{mg} /$ day was initiated for NSTEMI. There was segmentary wall motion abnormality on transthoracic echocardiography.

Since some of the high risk criteria, including high troponin and ST segment change on ECG, were present in our patient, we preferred an early invasive treatment strategy for our patient and performed coronary angiography within the first 24 hours of patients admission. There were severe stenotic lesions in the left anterior decending ( $L A D$ ) artery and right coronary artery (RCA). Percutaneous coronary intervention with bare metal stents was performed to all lesions and the patient was discharged the next day (Figure 2). The follow-up of 6 months was uneventful. Consent was obtained from the patient.

\section{Discussion}

The Kounis Syndrome was first described in 1991 and named the "allergic angina syndrome" (1, 2). This syndrome is also known as "allergic myocardial infarction". Drugs and various conditions can lead to the Kounis Syndrome. Antibiotics, analgesics, contrast media, intravenous anesthetics, nonsteroidal anti-inflammatory drugs and conditions like angio-edema, bronchial asthma, urticaria, food allergy, stings by ants and bees are the suspected drugs which might have a triggering effect for the Kounis Syndrome (3).

Two types of Kounis Syndrome have been described (4). The type I variant includes patients with normal coronary arteries. Release of inflammatory mediators acutely can induce either coronary artery spasm or coronary artery spasm progressing to acute myocardial infarction. The type II variant includes patients with underlying atheromatous disease and as in type I, contribution of released inflammatory mediators to an acute coronary event may lead to coronary artery spasm or progress to acute myocardial infarction. Recently, type III variant was described, which includes stent thrombosis as a result of hypersensitivity to drug eluting stents.

Constriction of the coronary arteries occur by release of mediators like histamine, leukotrienes, neutral proteases, and platelet-activating factor locally and to the systemic circulation by degranulation of mast cells which are located in the intimal layer of coronary arteries and

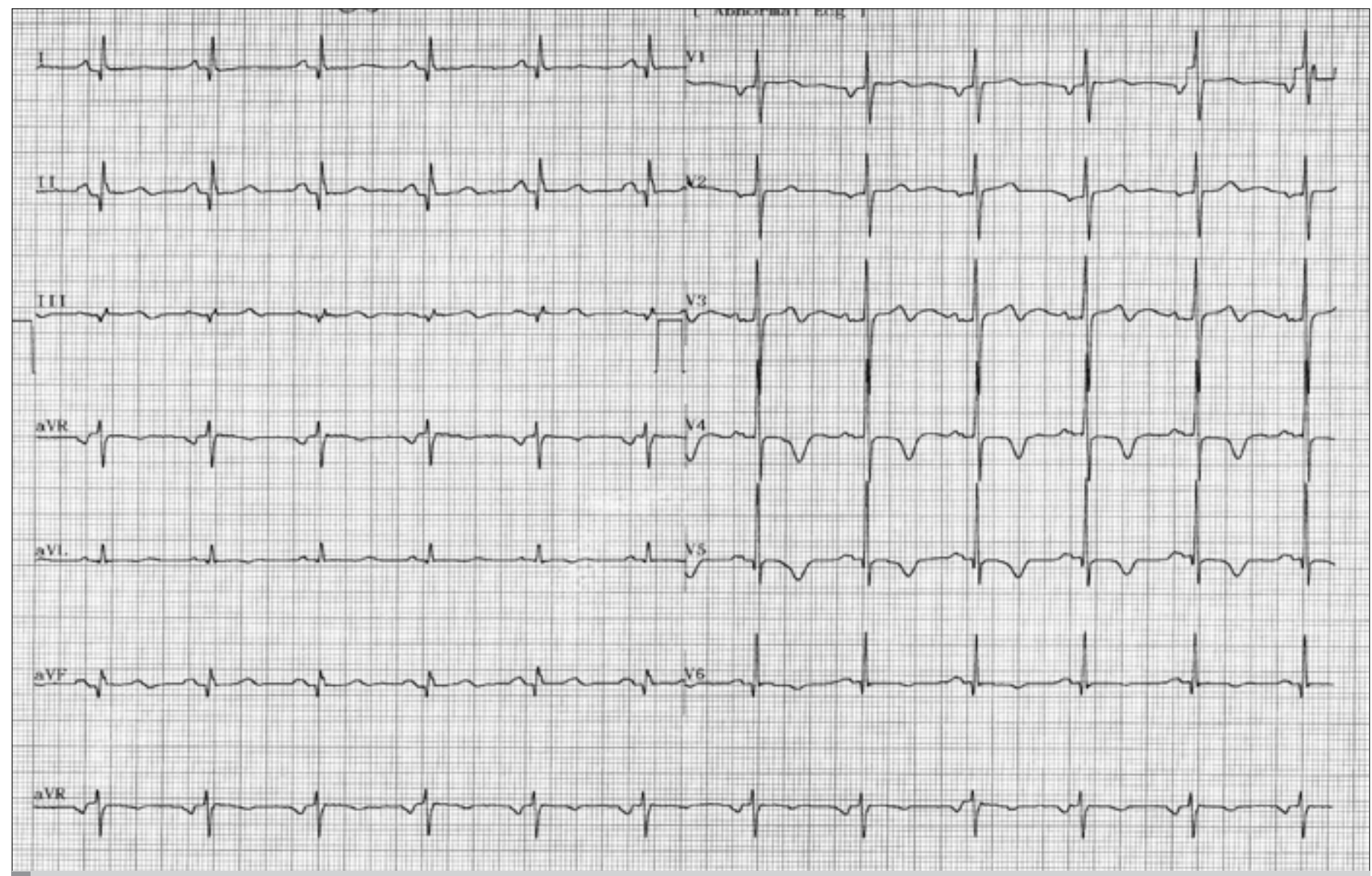

Figure 1. Ischemic ST changes on electrocardiography 


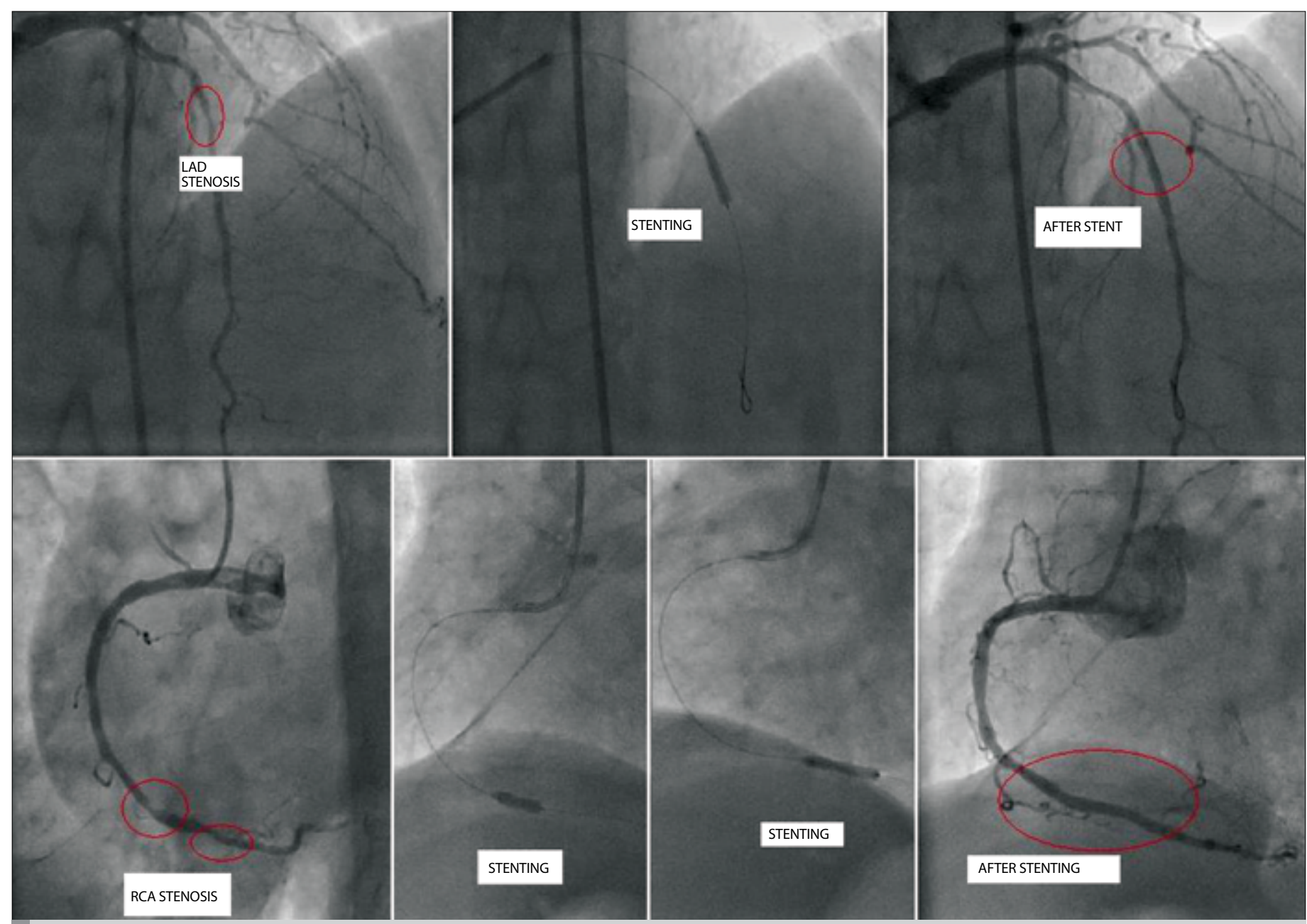

Figure 2. Stenotic lesions on left anterior decending (LAD) artery and right coronary artery (RCA)

atheromatous plaques during an allergic reaction (5). The most important point in the diagnosis of a Kounis Syndrome is suspicion in the patients with chest pain and a systemic allergic reaction. Systemic allergic reaction may occur within minutes to hours and presents with symptoms ranging from indiscriminable skin lesions to an obvious anaflactoid reaction. The present case is an example of type II variant Kounis Syndrom. The patient had prior coronary artery disease and underlying noncritical atheromatous plaque which became unstable and progressed to NSTEMI during the allergic event. Further evaluation of the patient's medical history a elucidated history of several allergic reactions. In this clinical event, the allergic reaction was triggered with metimazol sodium and aggravated by ampicillin/sulbactam.

\section{Conclusion}

This case report is an example of an allergic origin myocardial infarction which is defined as the Kounis Syndrome. In patients suffering chest pain after allergic reactions, the Kounis Syndrome must be kept in mind. Early diagnosis may be lifesaving in a serious clinical situation like NSTEMI.

Conflict of Interest: No conflict of interest was declared by the authors.
Peer-review: Externally peer-reviewed.

Informed Consent: Written informed consent was obtained from patient who participated in this case.

Author Contributions: Concept - A.O.B.; Design - B.Ş.; Supervision H.S., H.A.; Materials - M.O.C., Y.D.; Data Collection and/or Processing - M.O.C., Y.D.; Analysis and/or Interpretation - A.O.B., B.Ş.; Literature Review - A.O.B., B.Ş.; Writer - A.O.B.; Critical Review - H.S., H.A.

Financial Disclosure: The authors declared that this study has received no financial support.

Çıkar Çatışması: Yazarlar çıkar çatışması bildirmemişlerdir.

Hakem değerlendirmesi: Dış bağımsız.

Hasta Onamı: Yazılı hasta onamı bu olguya katılan hastadan alınmıştır.

Yazar Katkıları: Fikir - A.O.B.; Tasarım - B.Ş.; Denetleme - H.S., H.A.; Malzemeler - M.O.C., Y.D.; Veri toplanması ve/veya işlemesi - M.O.C., 
Y.D.; Analiz ve/veya yorum - A.O.B., B.Ş.; Literatür taraması - A.O.B., B.Ş.; Yazıyı yazan - A.O.B.; Eleştirel İnceleme - H.S., H.A.

Finansal Destek: Yazarlar bu çalışma için finansal destek almadıklarını beyan etmişlerdir.

\section{References}

1. Kounis NG, Grapsas GM, Goudevenos JA. Unstable angina, allergic angina and allergic myocardial infarction. Circulation 1999; 100: e156. [CrossRef]
2. Kounis NG, Zavras GM. Histamine-induced coronary artery spasm: the concept of allergic angina. Br J Clin Pract 1991; 45: 121-8.

3. Karasu E, Minareci K. Myocardial infarction following a bee sting: An example of Type II Kounis syndrome. Int J Cardiol 2011; 148: 382-4. [CrossRef]

4. Biteker M. A new classification of Kounis syndrome. Int J Cardiol 2010; 145: 553. [CrossRef]

5. Kounis NG. Kounis syndrome (allergic angina and allergic myocardial infarction): A natural paradigm? Int J Cardiol 2006; 110: 7-14. [CrossRef] 